\title{
Metabolic origins of childhood asthma
}

\author{
Hartmut Grasemann
}

\begin{abstract}
Childhood obesity and incidence of asthma are increasing globally. The parallel increase of the two suggests that obesity and asthma may be related and that abnormalities in the lipid and/or glucose metabolism may contribute to the pathogenesis of asthma. The clinical presentation of obese asthma is distinct from other asthma phenotypes and depending on age of onset of symptoms. Asthma in obese people tends to be more severe, not typically associated with allergy, and less responsive to standard anti-inflammatory therapy, including corticosteroids. Obesity and obesity-related comorbidities may lead to asthma via a number of mechanisms including changes in lung mechanics, the nitric oxide metabolism, and by causing inflammation. Furthermore, evidence suggests that nutrition during pregnancy contributes to intrauterine immune and metabolic programming in the offspring, which may have major influences on predisposition to cardiovascular, metabolic, and allergic diseases, including asthma, later in life. This review will highlight some suggested mechanistic links between obesity and diabetes with asthma.
\end{abstract}

Keywords: Obesity; Diabetes; Metabolism; Asthma; Intrauterine programming

\section{Introduction}

This review will summarize reported evidence of a possible link between obesity, diabetes mellitus, and asthma highlighting the potential roles of inflammation and abnormalities in the L-arginine/nitric oxide metabolism as well as metabolic and immune programming. An association between a greater body mass index (BMI) and increased risk of asthma in both children and adults has been repeatedly shown in prospective, population-based studies [1-5]. Nearly $30 \%$ of children are overweight or obese in the United States [6], where childhood obesity rates have tripled in the past three decades $[7,8]$. It is well known that obesity is associated with the development of insulin resistance and type II diabetes [9], but the increase in obesity also parallels an increase in the incidence of allergic disease in early life, particularly food allergy $[10,11]$, as well as asthma $[12,13]$.

The simultaneous increment in the prevalence of these conditions among children could be incidental but may also suggest common underlying predisposing or contributing factors and/or a causal relationship of metabolic conditions with allergic disease and specifically asthma [14-18]. For instance, the International Study of

\section{Correspondence: hartmut.grasemann@sickkids.ca}

Division of Respiratory Medicine, Department of Pediatrics, and Program in Physiology and Experimental Medicine, Research Institute, Hospital for Sick Children, and University of Toronto, 686 Bay St., 9th floor, Toronto, ON M5G 0A4, Canada
Asthma and Allergies in Childhood (ISAAC) Phase Three study demonstrated significant associations between overweight/obesity with asthma and eczema, but not rhinoconjunctivitis [19]. Interestingly, in some studies, the association between obesity and asthma was found to be stronger in non-atopic than atopic children $[20,21]$, and the association between BMI and asthma seems to be stronger among girls than boys [1,22-24]. Clinically important, obese asthmatics tend to present with more and severe symptoms and have poorly controlled asthma although they use more medications, and recovery from acute exacerbations is slower compared to their lean counterparts [25-28]. While it is conceivable that intensified treatments with high-dose inhaled or systemic corticosteroids as well as reduced physical activity in obese asthmatics contribute to weight gain, it is also important to notice that asthma-related outcomes in obese asthmatics can be improved with weight loss [29-31]. This not only provides further evidence for a causal role of obesity for asthma but also implies that weight loss should be attempted as supportive intervention in the treatment of obese/overweight asthmatics.

\section{Review}

\section{Phenotypic distinction}

A number of studies identified obesity in children and adolescents as a risk factor for asthma, more severe

\section{Springer}


asthma, poor asthma control, frequent exacerbations, and asthma-related hospitalizations [17,25,26,32-34]. The age of the weight gain may play a role, as pronounced weight gain early in life was identified as a risk factor for developing asthma in the first 6 years of age [35]. Two types of asthma in obese subjects can be distinguished by age of onset and clinical presentation. Early-onset asthma in obese presents before the age of 12 years, has no gender preference, and is characterized by severely decreased pulmonary function, significant airway hyperresponsiveness, and poor asthma control. These patients are atopic; serum immunoglobulin $\mathrm{E}$ (IgE) is increased, airway inflammation is eosinophilic, and fraction of exhaled nitric oxide (FeNO) is high [28]. In contrast, obese late-onset asthmatics become symptomatic after the age of 12 and are predominantly females without atopic characteristics. Compared to early-onset asthmatics, they have little airway obstruction with less airway hyperresponsiveness and better asthma control. This phenotype has a TH2 low profile with predominant neutrophilic airway infiltration [36], which may at least in part explain the poor response to standard asthma therapy in this patient group.

\section{Effect of obesity on pulmonary function and airway responsiveness}

Respiratory symptoms including shortness of breath with exercise in obese asthma may be mistaken for being related to the obesity alone; thus, pulmonary function testing should be performed to rule out a diagnosis of asthma. However, increased body fat deploys direct mechanical effects on the respiratory system independent of asthma. Obese individuals breathe at low tidal volumes and high respiratory rate. Increased BMI leads to a reduced functional residual capacity and expiratory reserve volume $[15,16]$. Pulmonary function tests in patients with BMI $>30$ may in addition reveal decreased total lung capacity, vital lung capacity, and residual volume [37]. Diabetes and insulin resistance have also been reported to be linked to lung function, and insulin resistance is associated with reduced lung function independent of diabetes, even after controlling for BMI [38-41].

Interestingly, impaired respiratory mechanics in obese people may also contribute to the development of asthma. Breathing at lower lung volumes results in airway narrowing and thereby increased resistance, which may contribute to airway hyperresponsiveness (AHR), a characteristic feature of asthma [42-45]. Whether obesity enhances or modifies AHR in children with asthma however remains unclear, as studies have revealed inconsistent results. No effect of BMI on AHR was found in participants of the Childhood Asthma Management Program (CAMP) after adjusting for baseline forced expiratory volume in the first second $\left(\mathrm{FEV}_{1}\right)$; in the CAMP study, more than 1,000 children with mild to moderate asthma were enrolled and followed to adulthood in the US and in Toronto, Canada [46]. Similarly, a prospective birth cohort study of more than 1,000 children from New Zealand found no effect of BMI on AHR [23]. Other studies suggested increased AHR to methacholine and worse exercise-induced bronchospasm in obese versus non-obese children and adolescents [47-50].

\section{Inflammation}

Adipose tissue is involved in the production and release of hormones as well as cytokines, which may both contribute to obesity-related insulin resistance, cardiovascular morbidities, hypertension, and metabolic disorders, as well as asthma [51,52]. Obesity is associated with increased adipocyte-driven pro-inflammatory activity resulting in chronic local and systemic inflammation [53,54]. One of the adipokines released by adipocytes is leptin, and serum leptin concentrations are increased in obesity. In children, increased serum leptin is associated with severity of exercise-induced bronchoconstriction [50], low-peak expiratory flow rate [55], and higher asthma prevalence in prepubertal boys [56], as well as peri- and postpubertal girls [57]. In contrast, adiponectin, which is also secreted from adipose tissue, is thought to inhibit the production and effects of pro-inflammatory cytokines such as tumor necrosis factor- $\alpha$ and interleukin (IL)- 6 and induces the expression of the anti-inflammatory cytokines IL-1 receptor antagonist and IL-10 [52]. Serum adiponectin levels have been reported to be associated with asthma severity [33], and adverse clinical outcomes of asthma [58], as well as exercise-induced bronchoconstriction in children $[50,52]$.

Adipokines may change the $\mathrm{T}$ helper cell balance in favor of a T helper cell type 1 (Th1) response, as it is seen in asthma associated with obesity $[59,60]$. Inflammation in allergic disease is usually dominated by Th2. However, airway disease in obese asthmatics is not typically characterized by eosinophilic/TH2 inflammation. In fact, obese children with asthma were found to have significantly higher Th1 and lower Th2 responses to specific stimuli compared with non-obese asthmatic children [61]. In support of this, studies in asthmatics have shown that increased BMI was inversely related to sputum eosinophils and FeNO $[25,62,63]$. Interestingly, neutrophil-predominant airway inflammation has also been described in obese women with asthma $[64,65]$, and weight loss by exercise or dietary changes results in a decrease in airway neutrophils [66].

\section{Nitric oxide and ADMA}

Asymmetric dimethylarginine (ADMA), a product of protein degradation, acts as competitive nitric oxide synthase (NOS) inhibitor and as such is involved in the pathogenesis of cardiovascular disease, diabetes, and asthma [67-70]. ADMA levels were increased in mouse lungs from a model of allergic airway inflammation [69] and also increased 
significantly in sputum from adult subjects with mild, eosinophilic asthma following a controlled inhaled allergen challenge [69]. In pediatric asthma, ADMA was found to be increased in exhaled breath condensate [71] and in sputum [69]. Sputum ADMA and decreased L-arginine: ADMA ratio, which can be used as a marker of NOS impairment, correlated with reduced FeNO [69]. The previously mentioned inverse association between BMI and FeNO in asthma $[62,63]$ may therefore be explained by an imbalance between NOS substrate L-arginine and its inhibitor, ADMA.

Interestingly, in a cross-sectional study of participants from the Severe Asthma Research Program (SARP), subjects with late-onset asthma (>12 years) had higher ADMA and lower L-arginine plasma levels compared to subjects with early-onset asthma [72]. The L-arginine: ADMA ratio in plasma was inversely correlated with BMI in late-onset, but not early-onset asthma, suggestive of NOS impairment in obese late-onset asthma. In addition, a reduced L-arginine:ADMA ratio in late-onset asthma was also associated with less serum IgE, increased respiratory symptoms, lower lung volumes, and worse asthma quality of life [72]. These studies demonstrated that clinical-biological phenotyping may help unravel relevant pathways in asthma beyond inflammation [73].

\section{Nutrition and developmental programming}

Certain nutrients, such as antioxidants and saturated fatty acids may represent a link between obesity and asthma [14], as they play an important role in oxidative lung damage and decreased lung defense against environmental hazards [41]. There is also increasing evidence that nutrition in infancy and even in utero has a major influence on later predisposition to cardiovascular, metabolic, and allergic diseases [74,75]. As recently reviewed elsewhere [41], abnormalities in the lipid and/or glucose metabolism early in life have the potential to contribute to the pathogenesis of lung disease and asthma later in life [41]. A healthy diet in pregnancy is important for lung development and innervation in the offspring, and imbalances can lead to airway hyperreactivity independent of the postnatal diet. In addition, the development of innate and adaptive immunity may also be affected by poor prenatal diet, which may result in increased susceptibility to infections with respiratory viruses such as respiratory syncytial virus and human rhinovirus, which both predispose to recurrent wheezing and asthma in childhood [41,76,77]. Metabolic and immune programming are also under epigenetic regulation, and there is increasing evidence now that nutrition can influence long-term health outcomes by modulation of epigenetic programming [78]. Interestingly, experimental studies have shown that immune programming can be modulated by the gut microbiome and that manipulation of the microbiome can prevent not only allergic disease $[79,80]$ but also the risk of obesity, cardiovascular, and metabolic disease [81].

\section{Conclusions}

In summary, the link between obesity and diabetes with asthma is complex. Metabolic disorders may affect the lungs in many ways, which includes changes in the mechanics of breathing, by causing or contributing to inflammation and abnormalities in the L-arginine metabolism and by modifying the metabolic and immune programming. Modification of the epigenetic programming through intrauterine exposures to environmental triggers including altered lipid and/or glucose metabolism of the mother may contribute to the observed increase in incident pediatric asthma. Supportive interventions in the treatment of obese/overweight asthmatics should include weight loss.

\section{Abbreviations}

ADMA: asymmetric dimethylarginine; AHR: airway hyperresponsiveness; BMI: body mass index; CAMP: Childhood Asthma Management Program; FeNO: fraction of exhaled nitric oxide; IgE: immunoglobulin $\mathrm{E}$; IL: interleukin; NOS: nitric oxide synthase; Th: T helper cell.

\section{Competing interests}

The author declares that he has no competing interests.

\section{Acknowledgements}

This is a review article written solely by Dr. Hartmut Grasemann; as a result, there is no one to acknowledge and no resources were used during the composition of this article.

Received: 12 November 2014 Accepted: 18 March 2015

Published online: 01 April 2015

\section{References}

1. Castro-Rodríguez JA, Holberg CJ, Morgan WJ, Wright AL, Martinez FD (2001) Increased incidence of asthmalike symptoms in girls who become overweight or obese during the school years. Am J Respir Crit Care Med 163(6):1344-1349

2. Mannino DM, Mott J, Ferdinands J, Camargo C, Friedman M, Greves H, Redd S (2006) Boys with high body masses have an increased risk of developing asthma: findings from the National Longitudinal Survey of Youth (NLSY). Int J Obes (Lond) 30(1):6-13

3. Gilliland FD, Berhane K, Islam T, McConnell R, Gauderman WJ, Gilliland SS, Avol E, Peters JM (2003) Obesity and the risk of newly diagnosed asthma in school-age children. Am J Epidemiol 158(5):406-415

4. Brumpton B, Langhammer A, Romundstad P, Chen Y, Mai X-M (2013) General and abdominal obesity and incident asthma in adults: the HUNT study. European Respiratory Journal 41(2):323-329

5. Camargo CA, Weiss ST, Zhang S, Willett WC, Speizer FE (1999) Prospective study of body mass index, weight change, and risk of adult-onset asthma in women. Arch Intern Med 159(21):2582-2588

6. Ogden C, Carroll M (2010) Prevalence of obesity among children and adolescents: United States trends 1963-1965 through 2007-2008. CDC National Center for Health Statistics. Available at: www.cdc.gov.

7. Wojcicki JM, Heyman MB (2010) Let's move-childhood obesity prevention from pregnancy and infancy onward. New England Journal of Medicine 362(16):1457-1459

8. Skinner AC, Skelton JA (2014) Prevalence and trends in obesity and severe obesity among children in the United States, 1999-2012. JAMA Pediatr 168 (6):561-566

9. Goran MI, Ball GD, Cruz ML (2003) Obesity and risk of type 2 diabetes and cardiovascular disease in children and adolescents. The Journal of Clinical Endocrinology \& Metabolism 88(4):1417-1427 
10. Mullins RJ (2007) Paediatric food allergy trends in a community-based specialist allergy practice, 1995-2006. Medical journal of Australia 186(12):618

11. Prescott S, Allen KJ (2011) Food allergy: riding the second wave of the allergy epidemic. Pediatr Allergy Immunol 22(2):155-160

12. (2007) Global surveillance, prevention and control of chronic respiratory diseases: a comprehensive approach. World Health Organization, Geneva, Switzerland. Available at http://www.who.int/gard/publications/ GARD_Manual/en/

13. Beasley R (1998) Worldwide variation in prevalence of symptoms of asthma, allergic rhinoconjunctivitis, and atopic eczema: ISAAC. The Lancet 351 (9111):1225-1232

14. Asher M, Keil U, Anderson H, Beasley R, Crane J, Martinez F, Mitchell E, Pearce N, Sibbald B, Stewart A (1995) International Study of Asthma and Allergies in Childhood (ISAAC): rationale and methods. European respiratory journal 8(3):483-491

15. Beuther DA, Weiss ST, Sutherland ER (2006) Obesity and asthma. Am J Respir Crit Care Med 174(2):112-119

16. Chinn S (2003) Obesity and asthma: evidence for and against a causal relation. Journal of Asthma 40(1):1-16

17. Rodriguez MA, Winkleby MA, Ahn D, Sundquist J, Kraemer HC (2002) Identification of population subgroups of children and adolescents with high asthma prevalence: findings from the Third National Health and Nutrition Examination Survey. Arch Pediatr Adolesc Med 156(3):269-275

18. Visness CM, London SJ, Daniels JL, Kaufman JS, Yeatts KB, Siega-Riz A-M, Liu AH, Calatroni A, Zeldin DC (2009) Association of obesity with lgE levels and allergy symptoms in children and adolescents: results from the National Health and Nutrition Examination Survey 2005-2006. Journal of Allergy and Clinical Immunology 123(5):1163-1169, e1164

19. Mitchell E, Beasley R, Björkstén B, Crane J, García-Marcos L, Keil U (2013) The association between BMI, vigorous physical activity and television viewing and the risk of symptoms of asthma, rhinoconjunctivitis and eczema in children and adolescents: ISAAC Phase Three. Clinical \& Experimental Allergy 43(1):73-84

20. Visness CM, London SJ, Daniels JL, Kaufman JS, Yeatts KB, Siega-Riz A-M, Calatroni A, Zeldin DC (2010) Association of childhood obesity with atopic and nonatopic asthma: results from the National Health and Nutrition Examination Survey 1999-2006. Journal of Asthma 47(7):822-829

21. Garcia-Marcos L, Arnedo Pena A, Busquets-Monge R, Morales Suárez-Varela M, García de Andoin N, Batlles-Garrido J, Blanco-Quirós A, López-Silvarrey Varela A, García-Hernández G, Aguinaga-Ontoso I (2008) How the presence of rhinoconjunctivitis and the severity of asthma modify the relationship between obesity and asthma in children 6-7 years old. Clinical \& Experimental Allergy 38(7):1174-1178

22. Figueroa-Munoz J, Chinn S, Rona R (2001) Association between obesity and asthma in 4-11 year old children in the UK. Thorax 56(2):133-137

23. Hancox RJ, Milne BJ, Poulton R, Taylor DR, Greene JM, McLachlan CR, Cowan JO, Flannery EM, Herbison GP, Sears MR (2005) Sex differences in the relation between body mass index and asthma and atopy in a birth cohort. Am J Respir Crit Care Med 171(5):440-445

24. Von Kries R, Hermann M, Grunert V, Von Mutius E (2001) Is obesity a risk factor for childhood asthma? Allergy 56(4):318-322

25. Quinto KB, Zuraw BL, Poon K-YT, Chen W, Schatz M, Christiansen SC (2011) The association of obesity and asthma severity and control in children. Journal of Allergy and Clinical Immunology 128(5):964-969

26. Giese JK (2014) Pediatric obesity and its effects on asthma control. Journal of the American Association of Nurse Practitioners 26(2):102-109

27. Taylor B, Mannino D, Brown C, Crocker D, Twum-Baah N, Holguin F (2008) Body mass index and asthma severity in the National Asthma Survey. Thorax 63(1):14-20

28. Holguin F, Bleecker ER, Busse WW, Calhoun WJ, Castro M, Erzurum SC, Fitzpatrick AM, Gaston B, Israel E, Jarjour NN (2011) Obesity and asthma: an association modified by age of asthma onset. Journal of Allergy and Clinical Immunology 127(6):1486-1493, e1482

29. Dias-Junior SA, Reis M, De Carvalho-Pinto RM, Stelmach R, Halpern A, Cukier A (2014) Effects of weight loss on asthma control in obese patients with severe asthma. Eur Respir J 43(5):1368-1377, 10.1183/09031936.00053413

30. Da Silva PL, De Mello MT, Cheik NC, Sanches PL, Correia FA, De Piano A, Corgosinho FC, Da Silveira Campos RM, Do Nascimento CM, Oyama LM (2012) Interdisciplinary therapy improves biomarkers profile and lung function in asthmatic obese adolescents. Pediatr Pulmonol 47(1):8-17
31. Eneli I, Skybo T, Camargo C (2008) Weight loss and asthma: a systematic review. Thorax 63(8):671-676

32. Black MH, Zhou H, Takayanagi M, Jacobsen SJ, Koebnick C (2013) Increased asthma risk and asthma-related health care complications associated with childhood obesity. Am J Epidemiol 178(7):1120-1128

33. Kattan M, Kumar R, Bloomberg GR, Mitchell HE, Calatroni A, Gergen PJ, Kercsmar CM, Visness CM, Matsui EC, Steinbach SF (2010) Asthma control, adiposity, and adipokines among inner-city adolescents. Journal of Allergy and Clinical Immunology 125(3):584-592

34. Borrell LN, Nguyen EA, Roth LA, Oh SS, Tcheurekdjian H, Sen S, Davis A, Farber HJ, Avila PC, Brigino-Buenaventura E (2013) Childhood obesity and asthma control in the GALA II and SAGE II studies. Am J Respir Crit Care Med 187(7):697-702

35. Brüske I, Flexeder C, Heinrich J (2014) Body mass index and the incidence of asthma in children. Curr Opin Allergy Clin Immunol 14(2):155-160

36. Rasmussen F, Hancox RJ (2014) Mechanisms of obesity in asthma. Curr Opin Allergy Clin Immunol 14(1):35-43

37. Jones RL, Nzekwu M-MU (2006) The effects of body mass index on lung volumes. Chest journal 130(3):827-833

38. Engström G, Hedblad B, Nilsson P, Wollmer P, Berglund G, Janzon L (2003) Lung function, insulin resistance and incidence of cardiovascular disease: a longitudinal cohort study. J Intern Med 253(5):574-581

39. Lawlor D, Ebrahim S, Smith GD (2004) Associations of measures of lung function with insulin resistance and type 2 diabetes: findings from the British Women's Heart and Health Study. Diabetologia 47(2):195-203

40. McKeever TM, Weston PJ, Hubbard R, Fogarty A (2005) Lung function and glucose metabolism: an analysis of data from the Third National Health and Nutrition Examination Survey. Am J Epidemiol 161(6):546-556

41. Perez MK, Piedimonte G (2014) Metabolic asthma: is there a link between obesity, diabetes, and asthma? Immunol Allergy Clin North Am 34(4):777-784

42. Chinn S, Jarvis D, Burney $P$ (2002) Relation of bronchial responsiveness to body mass index in the ECRHS. Thorax 57(12):1028-1033

43. Litonjua A, Sparrow D, Celedon J, DeMolles D, Weiss S (2002) Association of body mass index with the development of methacholine airway hyperresponsiveness in men: the Normative Aging Study. Thorax 57(7):581-585

44. Sposato B, Scalese M, Scichilone N, Pammolli A, Balducci MT, Migliorini MG, Scala R (2012) BMl can influence adult males' and females' airway hyperresponsiveness differently. Multidisciplinary respiratory medicine 7(1):45

45. Sharma S, Tailor A, Warrington R, Cheang M, Math M (2008) Is obesity associated with an increased risk for airway hyperresponsiveness and development of asthma? Allergy Asthma and Clinical Immunology 4(2):51

46. Tantisira K, Litonjua A, Weiss S, Fuhlbrigge A (2003) Association of body mass with pulmonary function in the Childhood Asthma Management Program (CAMP). Thorax 58(12):1036-1041

47. Jang A-S, Lee JH, Park SW, Shin MY, Kim DJ, Park C-S (2006) Severe airway hyperresponsiveness in school-aged boys with a high body mass index. Korean J Intern Med 21(1):10-14

48. Lopes W, Radominski R, Rosário Filho N, Leite N (2009) Exercise-induced bronchospasm in obese adolescents. Allergol Immunopathol 37(4):175-179

49. Huang S-L, Shiao G-M, Chou P (1999) Association between body mass index and allergy in teenage girls in Taiwan. Clin Exp Allergy 29:323-329

50. Baek H-S, Kim Y-D, Shin J-H, Kim J-H, Oh J-W, Lee H-B (2011) Serum leptin and adiponectin levels correlate with exercise-induced bronchoconstriction in children with asthma. Ann Allergy Asthma Immunol 107(1):14-21

51. Sood A, Shore SA (2013) Adiponectin, leptin, and resistin in asthma: basic mechanisms through population studies. J Allergy (Cairo) 2013:785835. doi: 10.1155/2013/785835.

52. Raj D, Kabra SK, Lodha R (2014) Childhood obesity and risk of allergy or asthma. Immunol Allergy Clin North Am 34(4):753-765

53. Shore SA (2008) Obesity and asthma: possible mechanisms. Journal of Allergy and Clinical Immunology 121(5):1087-1093

54. Wellen KE, Hotamisligil GS (2005) Inflammation, stress, and diabetes. Journal of Clinical Investigation 115(5):1111-1119

55. Gurkan F, Atamer Y, Ece A, Kocyigit Y, Tuzun H, Mete N (2004) Serum leptin levels in asthmatic children treated with an inhaled corticosteroid. Ann Allergy Asthma Immunol 93(3):277-280

56. Guler N, Kirerleri E, Ones U, Tamay Z, Salmayenli N, Darendeliler F (2004) Leptin: does it have any role in childhood asthma? Journal of Allergy and Clinical Immunology 114(2):254-259

57. Nagel G, Koenig W, Rapp K, Wabitsch M, Zoellner I, Weiland SK (2009) Associations of adipokines with asthma, rhinoconjunctivitis, and eczema in German schoolchildren. Pediatr Allergy Immunol 20(1):81-88 
58. Sood A, Dominic E, Qualls C, Steffes MW, Thyagarajan B, Smith LJ, Lewis CE, Jacobs DR Jr (2011) Serum adiponectin is associated with adverse outcomes of asthma in men but not in women. Frontiers in pharmacology 2:55, 10.3389/fphar.2011.00055. eCollection 2011

59. Tilg H, Moschen AR (2006) Adipocytokines: mediators linking adipose tissue, inflammation and immunity. Nat Rev Immunol 6(10):772-783

60. Baumann S, Lorentz A (2013) Obesity - a promoter of allergy. Int Arch Allergy Immunol 162(3):205-213

61. Rastogi D, Canfield SM, Andrade A, Isasi CR, Hall CB, Rubinstein A, Arens R (2012) Obesity-associated asthma in children: a distinct entity. CHEST Journal 141(4):895-905

62. Komakula S, Khatri S, Mermis J, Savill S, Haque S, Rojas M, Brown L, Teague GW, Holguin F (2007) Body mass index is associated with reduced exhaled nitric oxide and higher exhaled 8-isoprostanes in asthmatics. Respir Res 8(1):32-36

63. Van Veen I, Ten Brinke A, Sterk P, Rabe K, Bel E (2008) Airway inflammation in obese and nonobese patients with difficult-to-treat asthma. Allergy 63(5):570-574

64. Scott H, Gibson P, Garg M, Wood L (2011) Airway inflammation is augmented by obesity and fatty acids in asthma. European Respiratory Journal 38(3):594-602

65. Telenga E, Tideman S, Kerstjens H, Ten Hacken N, Timens W, Postma D, Den Berge M (2012) Obesity in asthma: more neutrophilic inflammation as a possible explanation for a reduced treatment response. Allergy 67(8):1060-1068

66. Scott H, Gibson P, Garg M, Pretto J, Morgan P, Callister R, Wood L (2013) Dietary restriction and exercise improve airway inflammation and clinical outcomes in overweight and obese asthma: a randomized trial. Clinical \& Experimental Allergy 43(1):36-49

67. Rochette L, Lorin J, Zeller M, Guilland J-C, Lorgis L, Cottin Y, Vergely C (2013) Nitric oxide synthase inhibition and oxidative stress in cardiovascular diseases: possible therapeutic targets? Pharmacol Ther 140(3):239-257

68. Tousoulis D, Papageorgiou N, Androulakis E, Siasos G, Latsios G, Tentolouris K, Stefanadis C (2013) Diabetes mellitus-associated vascular impairment: novel circulating biomarkers and therapeutic approaches. J Am Coll Cardiol 62(8):667-676

69. Scott JA, North ML, Rafii M, Huang H, Pencharz P, Subbarao P, Belik J, Grasemann H (2011) Asymmetric dimethylarginine is increased in asthma. Am J Respir Crit Care Med 184(7):779-785

70. Scott JA, Grasemann H (2014) Arginine metabolism in asthma. Immunol Allergy Clin North Am 34(4):767-775

71. Carraro S, Giordano G, Piacentini G, Kantar A, Moser S, Cesca L, Berardi M, Di Gangi IM, Baraldi E (2013) Asymmetric dimethylarginine in exhaled breath condensate and serum of children with asthma. CHEST 144(2):405-410

72. Holguin F, Comhair SA, Hazen SL, Powers RW, Khatri SS, Bleecker ER, Busse WW, Calhoun WJ, Castro M, Fitzpatrick AM (2013) An association between L-arginine/asymmetric dimethyl arginine balance, obesity, and the age of asthma onset phenotype. Am J Respir Crit Care Med 187(2):153-159

73. Sterk PJ, Ricciardolo FL (2013) Clinical-biological phenotyping beyond inflammation in asthma delivers. Am J Respir Crit Care Med 187(2):117-118

74. Barker DJ (1998) In utero programming of chronic disease. Clin Sci 95(2):115-128

75. Waterland RA, Michels KB (2007) Epigenetic epidemiology of the developmental origins hypothesis. Annu Rev Nutr 27:363-388

76. Daley D (2014) The evolution of the hygiene hypothesis: the role of early-life exposures to viruses and microbes and their relationship to asthma and allergic diseases. Curr Opin Allergy Clin Immunol 14(5):390-396

77. Rossi GA, Colin AA (2014) Infantile respiratory syncytial virus and human rhinovirus infections: respective role in inception and persistence of wheezing. Eur Respir J 45(3):774-789.

78. Palmer DJ, Huang R-C, Craig JM, Prescott SL (2014) Nutritional influences on epigenetic programming: asthma, allergy, and obesity. Immunol Allergy Clin North Am 34(4):825-837

79. Renz H (2011) Development and regulation of immune responses in pre-and postnatal life. Clin Biochem 44(7):495
80. Sudo N, Sawamura S-a, Tanaka K, Aiba Y, Kubo C, Koga Y (1997) The requirement of intestinal bacterial flora for the development of an IgE production system fully susceptible to oral tolerance induction. The Journal of Immunology 159(4):1739-1745

81. Turnbaugh PJ, Ley RE, Mahowald MA, Magrini V, Mardis ER, Gordon Jl (2006) An obesity-associated gut microbiome with increased capacity for energy harvest. Nature 444(7122):1027-1131

\section{Submit your manuscript to a SpringerOpen ${ }^{\circ}$ journal and benefit from:}

- Convenient online submission

- Rigorous peer review

- Immediate publication on acceptance

- Open access: articles freely available online

- High visibility within the field

- Retaining the copyright to your article

Submit your next manuscript at $>$ springeropen.com 